\author{
Vabischevich M., \\ Dedov 0., \\ Glitin $\mathbf{0}$.
}

\title{
EXPERIMENTAL DETERMINATION OF THE SPECTRUM OF STRUCTURE VIBRATIONS UNDER THE INFLUENCE OF TECHNOLOGICAL LOAD
}

Об'єктом досліджень є процес розповсюдження коливань від технологічного обладнання на металоконструкції споруди. Однією з проблем при обстеженні і моніторингу будівельних об'єктів є оцінка вібраційної дії технологічного обладнання на несучі елементи споруди. Існуючі нормативні документи і методики врахування динамічного впливу неповною мірою охоплюють дану проблему, про що свідчить наявність випадків аварійного стану експлуатованих споруд, які піддані динамічним навантаженням.

Запропоновано підхід, в основу якого покладена гіпотеза про розгляд споруди і технологічного обладнання, що має динамічний вплив, як єдиної системи із відповідними ій динамічними характеристиками. Реалізація такого підходу може бути здійснена шляхом визначення інтегральних динамічних параметрів системи з подальшим аналізом і встановленням причинно-наслідкових зв'язків. В ході дослідження використовувалися записи безперервної фіксації параметрів динамічної дії на елементах будівельної конструкції, які були визначені на основі попереднього аналізу. В результаті аналізу віброграм побудовані спектри коливань споруди, за якими визначені домінуючі частоти коливань, що складають 3.470 та 3.625 Ги. Встановлені частоти відповідають основним частотам і їх гармонікам реалізації технологічного прочесу за технічними характеристиками обладнання, що складають 3.670 Ги. Виявлені явища внутрішнвого резонансу загальної системи споруди технологічного цеху дозволили чітко сформулювати причини появи надмірних коливань. Виконані експериментальні дослідження впливу технологічного обладнання на каркас споруди. Розроблена скінчено-елементна модель каркасу на основі інструментального обстеження будівлі.

Отримані результати досліджень можуть бути використані при розробиі методик $і$ технологій діагностування та встановлення причин надмірних коливань несучих і огороджувальних конструкиій споруд при дї̈ динамічного навантаження техногенного походження.

Ключові слова: обстеження споруди, вібраційна діагностика, власні частоти коливань, форма коливань, динамічне навантаження, скінченно-елементна модель.

Received date: 12.06 .2019

Accepted date: 25.06 .2019

Published date: 30.08 .2019
Copyright (C) 2019, Vabischevich M., Dedov O., Glitin O. This is an open access article under the CC BY license (http://creativecommons.org/licenses/by/4.0)

\section{Introduction}

In modern production conditions, there is the problem of restructuring production using the latest technologies and the use of energy-efficient materials processing processes. The tendency to create new industries lies in the plane of use of existing buildings and their re-equipment for production facilities using the latest equipment. Such a technology is quite justified in terms of cost savings for the construction of new structures. But quite often, existing buildings for several reasons turn out to be unsuitable for the use of one or another technological equipment, and as a result, emergency conditions can be detected during the operation of such structures. Among the reasons that lead to negative consequences, the most common are: deterioration of the structure, violation of equipment installation requirements, lack of proper calculations on the mutual influence of equipment and structures. As a rule, the deterioration of the structure and the correctness of the installation work can be resolved as part of a general instrumental examination of the construction site. The installation of the mutual influence between the construction and equipment requires more in-depth research and appropriate calculations.

A number of works are devoted to studying the dynamic behavior of building structures under the influence of external factors. As a rule, the dynamic action on the structure is considered as a seismic and technogenic character. So, in [1], the results of measurements of microseismic effects are presented and a technique and experimental studies based on the determination of dynamic parameters are proposed. In [2], a method is proposed for assessing the influence of railway vibration on adjacent buildings and the propagation of such vibration through a soil mass. In [3], research is given on the use of additional building structures to extinguish vibration effects, the proposed model and methodology for taking into account the dynamic parameters of a structure and vibration damper. Experimental studies based on measurements of accelerations are given in [4]. On the basis of the constructed vibration spectrum, the natural vibration frequencies are determined. The described technique can be used in the study of more complex dynamic systems. 
Measurements of the dynamic characteristics of systems for the purpose of diagnosis and monitoring of existing defects in metal structures are presented in [5]. The methodology for the application of experimental studies of vibration and their processing is presented [6]. The improvement of the calculation model based on the obtained dynamic characteristics is proposed. The application of the method to nonlinear active vibration control systems is presented in [7]. According to the authors, this method allows to get a result without significant knowledge about the dissipative properties of the system, of course it gives advantages and reduces the time for research. On measuring instruments, it is possible to use different types of sensors. So, in [8], acceleration measurement sensors are used. The remote measurement given in [9] is based on the use of laser and optical devices. And the use of a vibration sensor based on optical fiber is proposed in [10]. Of course, such data acquisition systems are highly accurate and sensitive. But their use is limited by high cost.

Despite a significant number of publications and a wide range of tasks that are considered in them, the study of the behavior of building structures under the influence of dynamic load is an important area of both theoretical and experimental research.

Thus, the object of research is the process of propagation of vibrations from technological equipment to the metal structures of the building. And the aim of research is determination of the behavior of the metal frame of the production workshop under the influence of dynamic load.

\section{Methods of research}

Experimental studies were carried out in the conditions of operation of a construction object - the building of a technological workshop, during an instrumental examination of its technical condition. The main task of the technical examination is in determination of the causes of overtime vibrations of the external wall of the technological workshop during the long-term operation of the technological equipment.

The construction of the technological workshop in the plan has a rectangular shape with overall dimensions of $53.865 \times 17.70 \mathrm{~m}$. The height of the building to the lower zone of the coating farms is $10.535 \mathrm{~m}$.

Columns - made of hot-rolled channels No. 20, connected by intermittent welds in a «box». Between the columns there is a system of vertical ties.

Coverage - a system of steel trusses made from equal iron corners. At the level of the upper truss belts, coating runs are made of square bent welded pipes to which the construction of a stacked sandwich is attached. There are no horizontal and vertical ligatures between the farms.

Communication items. The spacers between the columns are made of bent channels $160 \times 65$ welded into a «box». Vertical ligature - from channel number 14.

The external walls are stacked, combined: the lower part (up to +5.000) is made of foam blocks, the upper part is a stacked sandwich.

Foundations - shallow laying, monolithic, reinforced concrete, laying depth $1.15 \mathrm{~m}$, sole width $1.30 \times 1.35 \mathrm{~m}$.

To carry out work on measuring and obtaining real values of the vibrations of various points of the structure, the ZET 048C seismograph (Russia) is used, the technical data of which are given in Table 1 .
Table 1

ZET 048C accelerometer technical specifications

\begin{tabular}{|l|c|}
\hline Type of sensors & differentials \\
\hline The number of measured coordinates & $3(X, Y, Z)$ \\
\hline Measurement parameter & vibration acceleration \\
\hline Working range, $\mathrm{Hz}$ & from 0.3 to 400 \\
\hline Sensitivity & no more than $10^{-5} \mathrm{~m} / \mathrm{s}^{2}$ \\
\hline The main relative error, \% & no more than \pm 10 \\
\hline Working temperature, ${ }^{\circ} \mathrm{C}$ & from -30 to +50 \\
\hline
\end{tabular}

The research consisted in the experimental measurement of the motion parameters of the elements of the supporting structures in real time with their subsequent processing and determination of the dynamic characteristics of such elements and the structure as a whole.

As a dynamic criterion for assessing the state of loadbearing structures, the values of natural vibration frequencies were used.

To determine the dynamic parameters, five control points were selected, a list of which is given in Table 2 .

Table 2

Location of static monitoring control points

\begin{tabular}{|c|c|c|c|}
\hline $\begin{array}{c}\text { Control } \\
\text { point }\end{array}$ & Feature Description & $\begin{array}{c}\text { Number of } \\
\text { measurement sensors }\end{array}$ & $\begin{array}{c}\text { Controlled } \\
\text { parameter }\end{array}$ \\
\hline P1C1 & Ground floor & $3(X, Y, Z)$ & \multirow{2}{*}{ Vibration } \\
\cline { 1 - 2 } P1C2 & Tubular wall element & $3(X, Y, Z)$ & \\
\cline { 1 - 2 } P1C3 & Leveleration 2 flooring & $3(X, Y, Z)$ \\
\cline { 1 - 2 } P1C4 & Level 2 flooring & $3(X, Y, Z)$ & \\
\hline P1C5 & Level 3 flooring & $3(X, Y, Z)$ & \\
\hline
\end{tabular}

The recorded vibration programs of the building vibrations at the control points were to be processed using the ZETLAB SEISMO software using spectral analysis using the discrete Fourier transform method.

The obtained spectra were analyzed in order to determine the numerical values of the vibration frequencies corresponding to the main peaks in the spectrograms and were a consequence of the design recall to external vibration sources.

The design scheme of the frame and its supporting elements is adopted in accordance with the known rules of building mechanics. The static diagram of ordinary transverse frames is adopted with rigid support on the foundation of the columns, articulation of the outermost columns with the truss and with a rigid connection of the starting elements of the crossbar in the mounting nodes. The support of roofing girders on the trusses of the coating is assumed to be hinged (split diagram).

Static and modal structural analysis was performed in a linear formulation using the Scad Office computing system, based on the use of the finite element method.

\section{Research results and discussion}

During field measurements of structural vibrations, vibration programs of vibrations at control points were obtained. Recorded vibrations show that the intensity of vibrational vibrations on a structure increases with increasing 
height and decreasing distance to sources of technological, external influence.

Fluctuations in the frame wall (Fig. 1) indicate a mode close to resonance (beat mode) and are a consequence of the overlapping of less than two frequencies close in numerical value. In addition, one of them is the frequency of natural vibrations of the structure with its corresponding form of vibration.

As a result of the analysis of vibrograms, the spectral distribution of vibration frequencies at each control point is obtained. The vibrational spectrum at the control point P1C2 (Fig. 2) has two distinct peaks, the values of which are, respectively, 3.470 and $3.625 \mathrm{~Hz}$. Obviously, it is precisely these values of the frequencies that are the reason for the appearance of wall structures close to the resonance regime of vibrations, since peaks with other (higher) numerical values of the vibration frequencies appear to a lesser extent.

Similar peaks were found at the control points $\mathrm{P} 1 \mathrm{C} 3-\mathrm{P} 1 \mathrm{C} 5$ with the same values of vibration frequencies, but of lower intensity, which indicates the transfer of vibrations from the building frame of the building frame to the supporting elements for technological purposes.

The results of the numerical modal analysis of the completed elemental model of the structure framework are given in Table 3 .

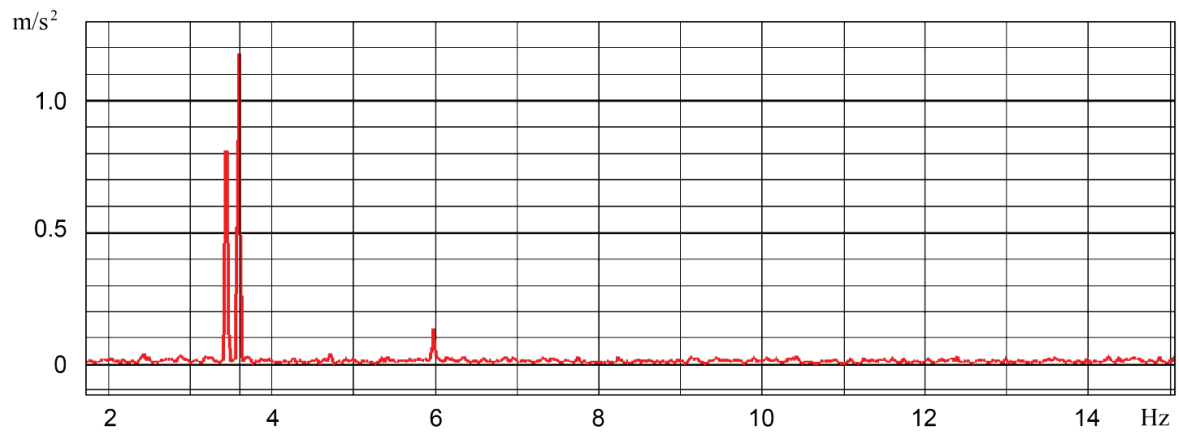

Fig. 2. The frequency spectrum of the vibrations P1C2 in the frequency range from 0 to $10 \mathrm{~Hz}$

Table 3

Periods and frequencies of natural vibrations

\begin{tabular}{|c|c|c|c|c|c|c|c|c|}
\hline \multirow{2}{*}{\multicolumn{2}{|c|}{ Load }} & \multirow{3}{*}{$\begin{array}{c}\begin{array}{c}\text { Form } \\
\text { number }\end{array} \\
1\end{array}$} & \multicolumn{2}{|c|}{ Frequencies } & \multirow{3}{*}{$\begin{array}{c}\text { Period } \\
5 \\
2.248\end{array}$} & \multicolumn{3}{|c|}{ Modal masses (\%) } \\
\hline & & & \multirow{2}{*}{$\frac{\mathrm{rad} / \mathrm{s}}{2.795}$} & \multirow{2}{*}{$\frac{\mathrm{Hz}}{0.445}$} & & \multirow{2}{*}{$\frac{X}{0.021}$} & \multirow{2}{*}{$\frac{Y}{80.865}$} & \multirow{2}{*}{$\frac{Z}{0}$} \\
\hline \multirow{16}{*}{7} & \multirow{16}{*}{$\begin{array}{c}\text { Modal } \\
\text { analysis }\end{array}$} & & & & & & & \\
\hline & & 2 & 4.059 & 0.646 & 1.548 & 56.264 & 0.378 & 0.011 \\
\hline & & 3 & 4.76 & 0.758 & 1.32 & 5.105 & 2.722 & 0 \\
\hline & & 4 & 8.934 & 1.422 & 0.703 & 0.078 & 2.464 & 0 \\
\hline & & 5 & 9.267 & 1.475 & 0.678 & 0.013 & 0.602 & 0 \\
\hline & & 6 & 11.503 & 1.831 & 0.546 & 23.039 & 0 & 0 \\
\hline & & 7 & 13.883 & 2.21 & 0.453 & 1.53 & 0 & 0 \\
\hline & & 8 & 15.838 & 2.521 & 0.397 & 0 & 0.04 & 0.03 \\
\hline & & 9 & 17.011 & 2.707 & 0.369 & 0.015 & 0.973 & 0 \\
\hline & & 10 & 17.529 & 2.79 & 0.358 & 0 & 0.013 & 0 \\
\hline & & 11 & 17.84 & 2.839 & 0.352 & 0 & 3.175 & 0 \\
\hline & & 12 & 21.095 & 3.357 & 0.298 & 0.017 & 0.016 & 0 \\
\hline & & 13 & 23.057 & 3.67 & 0.273 & 0.056 & 0.082 & 0.047 \\
\hline & & 14 & 23.598 & 3.756 & 0.266 & 1.628 & 0.011 & 0.019 \\
\hline & & 15 & 24.839 & 3.953 & 0.253 & 3.786 & 0.199 & 2.021 \\
\hline & & & Sum of th & adal mas & & 91.558 & 91.544 & 2.154 \\
\hline
\end{tabular}

According to the calculation re-

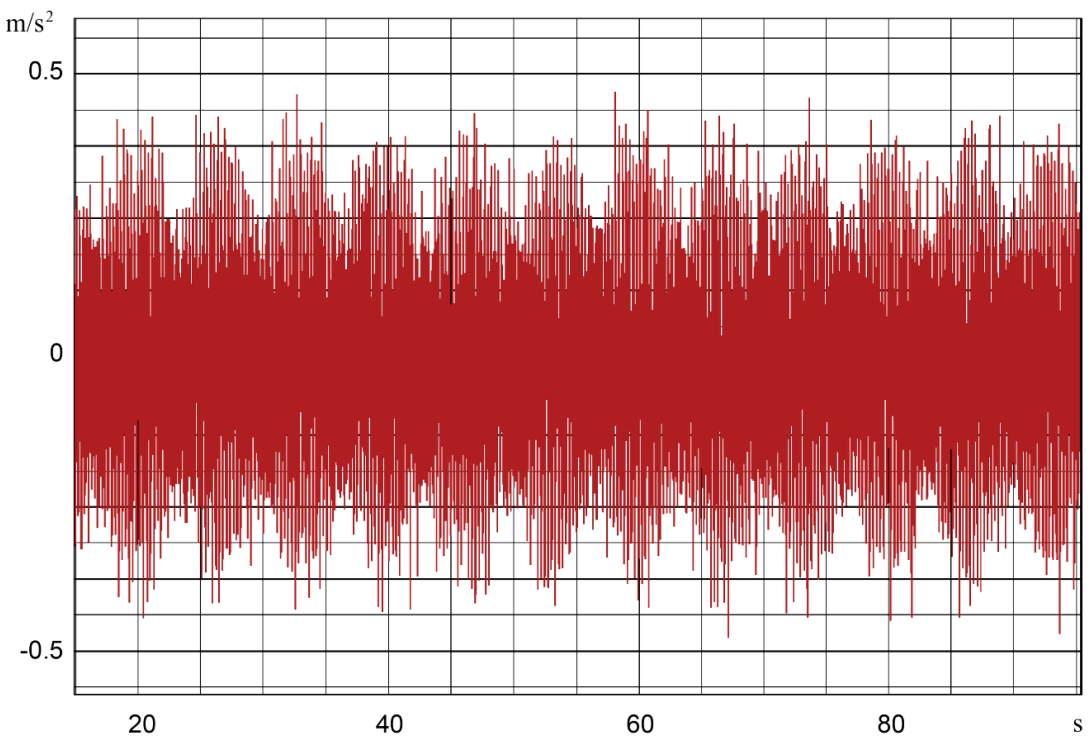

Fig. 1. Vibrogram of vibrations in control point P1C2 sults, it is found that the frequencies of the 13th form of natural vibrations (3.67 Hz) actually coincide with the forced ones. It is these frequency values that led to the appearance of a wall structure of an industrial building close to the resonant regime of vibrations.

\section{Conclusions}

In the work, according to the results of measuring the dynamic parameters of motion of the elements of the supporting structures of an industrial structure under the influence of technological equipment, vibration frequencies of 3.470 and $3.625 \mathrm{~Hz}$ are determined. It is these values of frequencies that are the cause of the appearance of wall structures close to the resonance regime of vibrations 
(Fig. 1). A calculated finite element model of the framework of the construction of the technological workshop is developed, the vibrations of which are investigated.

Static and modal analysis of the finite element model of the carcass in a linear formulation using the Scad Office computing system, based on the use of the finite element method, has been performed. It is established that the calculated frequency of the 13th form of natural vibrations $(3.67 \mathrm{~Hz})$ is close to the experimentally determined dominant vibration frequencies. It is these frequency values that led to the appearance of a wall structure of an industrial building close to the resonant regime of vibrations.

\section{References}

1. Shcherbina, S. V., Britskyi, O. I., Ilienko, V. A., Bielov, I. D., Ostapenko, V. V., Lisovyi, Yu. V. et. al. (2016). Doslidzhennia provalnykh yavyshch $\mathrm{v}$ istorychnii chastyni Kyieva na terytorii natsionalnoho zapovidnyka «Sofiia Kyivska». Heoinformatyka, 2, 68-78.

2. Connolly, D. P., Kouroussis, G., Giannopoulos, A., Verlinden, O., Woodward, P. K., Forde, M. C. (2014). Assessment of railway vibrations using an efficient scoping model. Soil Dynamics and Earthquake Engineering, 58, 37-47. doi: http://doi.org/10.1016/ j.soildyn.2013.12.003

3. Cacciola, P., Banjanac, N., Tombari, A. (2017). Vibration Control of an existing building through the Vibrating Barrier. Procedia Engineering, 199, 1598-1603. doi: http://doi.org/10.1016/ j.proeng.2017.09.065

4. Kavyanpoor, M., Shokrollahi, S. (2019). Dynamic behaviors of a fractional order nonlinear oscillator. Journal of King Saud University - Science, 31 (1), 14-20. doi: http://doi.org/10.1016/ j.jksus.2017.03.006

5. Bendjama, H., Bouhouche, S., Boucherit, M. S. (2012). Application of Wavelet Transform for Fault Diagnosis in Rotating Machinery. International Journal of Machine Learning and Computing, 2 (1), 82-87. doi: http://doi.org/10.7763/ ijmlc.2012.v2.93
6. Giagopoulos, D., Arailopoulos, A., Dertimanis, V., Papadimitriou, C., Chatzi, E., Grompanopoulos, K. (2017). Computational Framework for Online Estimation of Fatigue Damage using Vibration Measurements from a Limited Number of Sensors Procedia Engineering, 199, 1906-1911. doi: http://doi.org/ 10.1016/j.proeng.2017.09.424

7. Yamamoto, G. K., da Costa, C., da Silva Sousa, J. S. (2016) A smart experimental setup for vibration measurement and imbalance fault detection in rotating machinery. Case Studies in Mechanical Systems and Signal Processing, 4, 8-18. doi: http:// doi.org/10.1016/j.csmssp.2016.07.001

8. Jia, Y., Seshia, A. A. (2014). An auto-parametrically excited vibration energy harvester. Sensors and Actuators A: Physical, 220, 69-75. doi: http://doi.org/10.1016/j.sna.2014.09.012

9. Lezhin, D. S., Falaleev, S. V., Safin, A. I., Ulanov, A. M., Vergnano, D. (2017). Comparison of Different Methods of Noncontact Vibration Measurement. Procedia Engineering, 176, 175-183. doi: http://doi.org/10.1016/j.proeng.2017.02.286

10. Gianti, M. S., Prasetyo, E., Wijaya, A. D., Berliandika, S., Marzuki, A. (2017). Vibration Measurement of Mathematical Pendulum based on Macrobending-Fiber Optic Sensor as a Model of Bridge Structural Health Monitoring. Procedia Engineering, 170, 430-434. doi: http://doi.org/10.1016/j.proeng.2017.03.069

Vabischevich Maksim, PhD, Department of Structural Mechanics, Kyiv National University of Construction and Architecture, Ukraine, e-mail:vabix@ukr.net, ORCID: https://orcid.org/00000002-0755-5186

Dedov Oleg, PhD, Associate Professor, Department of Machinery and Equipment of Technological Processes, Kyiv National University of Construction and Architecture,Ukraine, e-mail:dedovvcbk@ukr.net, ORCID: https://orcid.org/0000-0001-5006-772X

Glitin Oleksandr, PhD, Associate Professor, Department of Metal and Wooden Structures, Kyiv National University of Construction and Architecture,Ukraine, e-mail: glitin@ukr.net, ORCID: https:// orcid.org/0000-0003-1697-6473 